\title{
ETIKA BERMEDIA SOSIAL BAGI GENERASI MUDA GEREJA
}

\author{
Yonna Beatrix Salamor ${ }^{1}$, Anna Maria Salamor ${ }^{2}$ \\ ${ }^{1,2}$ Program Studi Ilmu Hukum, Fakultas Hukum, Universitas Pattimura \\ e-mail: yonnahukum@gmail.com
}

\begin{abstract}
Abstrak
Perkembangan teknologi informasi terus mengalami perkembangan yang luar biasa khususnya teknologi telekomunikasi, media dan informasi. Salah satu bentuk kongkrit dari Teknologi tersebut adalah komputer dan internet yang telah menjadi bagian aktifitas manusia modern. Kehadiran informasi dan teknologi (IT) tanpa disadari telah membentuk masyarakat baru. Melalui pengembangan jaringan/jejaring (network) dengan sistem sarang laba-laba. Adanya asumsi bahwa Internet saat ini dapat dengan mudah diakses melalui ponsel pintar atau smartphone pada dasarnya adalah media yang netral, maka manusia sebagai pengguna yang dapat menentukan tujuan media tersebut digunakan dan manfaat yang dapat diambil. Berdasarkan asumsi tersebut, maka pendidikan media dan pemahaman akan penggunaannya menjadi suatu hal yang penting bagi semua orang. Terutama bagi para generasi muda yang kerap menggunakan Internet untuk mencari beragam informasi untuk menunjang pendidikannya. Pemahaman dan penggunaan media ini disebut literasi media Internet. Metode yang digunakan dalam penyuluhan hukum bagi AM GPM Ranting Militia Christy kami berharap melalui kegiatan ini dapat memberikan dampak positif bagi generasi muda gereja dalam peningkatan kesadaran dan etika memakai media sosial dengan bijak.
\end{abstract}

Kata Kunci: Kesadaran Hukum, Etika, Media Sosial.

\begin{abstract}
The development of information technology continus to experience extraordinary development, especially telecommunications, media and information technology. One concrete form of this technology is computers and the internet which have become part of modern human activities. The presence of information and technology (IT) has unwittingly formed a new society. Through network development with a cobweb system. There is an assumption that the internet today can be easily accessed via smart phones or smartphones is basically a neutral media, so humans as users can determine the purpose of the media being used and the benefits that can be taken. Based in these assumptions, media education and understanding of its use are important for everyone. Especially for the younger generation who often use the internet to find a variety of information to support their education. This understanding and use of media is called internet media literacy. The method used in legal counseling for AM GPM Militia Christy Twig we hope that through this activity can have a positive impact for the younger generation of the church in raising awareness and ethics wear social media wisely.
\end{abstract}

Keywords: Awareness Of Law, Ethics, Social Media.

\section{PENDAHULUAN}

Perkembangan teknologi komunikasi yang diiringi dengan kehadiran media massa juga telah memberi banyak perubahan dalam kehidupan bermasyarakat. Saat di mana kita hidup sekarang ini dapat dikatakan sebagai era digital. Dalam era digital semacam ini dunia berada dalam genggaman kita. Sekalipun kita hanya berada pada satu tempat dan satu waktu, namun kita dapat memantau keadaan di seluruh dunia, bahkan kita dihubungkan melalui media sosial dengan semua orang. Kita juga tidak dapat membendung arus informasi yang mengalir begitu deras, tidak hanya melalui media massa, namun juga melalui media sosial.

Media sosial saat ini tidak hanya dipandang sebagai ajang bersosialisasi di dunia maya semata, namun sudah berkembang menjadi ajang menuangkan ide-ide dalam pribadi seseorang yang berkaitan dengan banyak aspek serta membagikannya kepada orang lain.

Dengan semakin berkembangnya media sosial di Indonesia, semakin mudah dan banyak pula opini masyarakat yang disalurkan melalui media sosial di internet. Dengan demikian, suatu informasi, berita, kabar dapat tersebar begitu cepatnya. Tidak mengherankan jika kini segala bidang tak akan 
bisa lepas dari yang namanya internet dan media sosial. Selain itu, masyarakat mulai mampu untuk berpikir kritis dan berwawasan luas sehingga peran serta masyarakat bisa lebih terasa.

Adanya asumsi bahwa Internet saat ini dapat dengan mudah diakses melalui ponsel pintar atau smartphone pada dasarnya adalah media yang netral, maka manusia sebagai pengguna yang dapat menentukan tujuan media tersebut digunakan dan manfaat yang dapat diambil. Berdasarkan asumsi tersebut, maka pendidikan media dan pemahaman akan penggunaannya menjadi suatu hal yang penting bagi semua orang. Terutama bagi para generasi muda yang kerap menggunakan Internet untuk mencari beragam informasi untuk menunjang pendidikannya. Pemahaman dan penggunaan media ini disebut literasi media Internet.

Kondisi demikian memerlukan perhatian khusus dalam meningkatkan kesadaran dari generasi muda gereja untuk menggunakan bahasa yang bijak di media sosial pada era digitalisasi saat ini. Salah satu upaya yang dapat dilakukan untuk meminimalisir dampak negatif dari penggunaan media sosial adalah dengan meningkatkan kesadaran akan data yang bersifat privasi dan meningkatkan literasi penggunaan internet. Berdasarkan uraian singkat yang dilakukan maka yang menjadi judul dalam kegiatan pengabdian masyarakat yang dilakukan yaitu Etika Bermedia Sosial Bagi Generasi Muda Gereja. Adapun masalah yang menjadi latarbelakang dilaksanakan kegiatan pengabdian masyarakat ini adalah bagaiamana cara generasi muda gereja dalam bersosial media dimasa pandemic Covid 19.

\section{METODE}

Kegiatan pengabdian kepada masyarakat yang dilaksanakan di Angkatan Muda Ranting Militia Christy merupakan sebuah kegiatan pengabdian masyarakat yang dilakukan dengan beberapa tahapan yaitu:

a. Melakukan identifikasi masalah yang dihadapi oleh kader-kader AM GPM Ranting Militia Christy.

b. Memberikan penyuluhan tentang etika bermedia sosial bagi kader AM GPM Ranting Militia Christy.

Dari tahapan-tahapan yang dilakukan, maka metode yang digunakan dalam kegiatan pengabdian kepada masyarakat di AM GPM Ranting Militia Christy adalah metode penyuluhan hukum tentang etika bersosial media bagi kader AM GPM Ranting Militia Christy.

\section{HASIL DAN PEMBAHASAN}

Cara bersosial media yang baik

Perkembangan teknologi informasi terus mengalami perkembangan yang luar biasa khususnya teknologi telekomunikasi, media dan informatika (TELEMATIKA). Salah satu bentuk kongkrit dari Teknologi tersebut adalah komputer dan internet yang telah menjadi bagian aktifitas manusia modern. Kehadiran informasi dan teknologi (IT) tanpa disadari telah membentuk masyarakat baru. Melalui pengembangan jaringan/jejaring (network) dengan sistem sarang laba-laba.

Bersamaan dengan perkembangan teknologi yang semakin canggih dan semakin merasuk dalam aktivitas kehidupan manusia di tengah arus globalisasi yang semakin meluas. Masyarakat maya telah membangun sistem kemasyarakatan sebagaimana model dalam segi kehidupan masyarakat nyata seperti interaksi sosial, stratifikasi sosial, kebudayaan, pranata sosial, kekuasaan dan juga kejahatan.

Perkembangan IT bagi generasi muda membawa dampak positif dan dampak negatif. Dampak positifnya adalah mencari akses informasi apapun lebih cepat, akurat, terbaru di bumi bagian manapun, dapat berkomunikasi dengan teman, keluarga jauh hanya dengan teknologi yang tersedia serta memberikan kemudahan atau cara baru dalam melakukan aktifitas manusia.

Selain itu dapat menghemat waktu dan biaya dalam beraktivitas. Sedangkan dampak negatif dari IT adalah dengan jejaring sosial menjadikan orang jarang berhubungan langsung dengan orang lain (pola interaksi yang berubah), semakin lemahnya sikap ramah tamah, gotong royong, sopan santun. Penggunaan IT dapat disalahgunakan oleh pihak-pihak tertentu untuk tujuan tertentu. Yang harus diwaspadai oleh generasi muda dalam menghadapi ada perkembangan IT adalah munculnya beberapa kejahatan IT diantaranya pornografi, teror berbau seksual, religious serta kegiatan melanggar privasi orang lain.

Akses kepada media sosial telah berkembang dengan luas, namun hanya beberapa saja jejaring sosial yang diminati di Indonesia, antara lain: Youtube, WhatsApp, Facebook, Instagram, Tiktok, Line, 
Twitter, Reddit, Pinterest, dan Tumblr. Media sosial menjadi wadah bagi generasi muda gereja untuk mengekspresikan seluruh perasaannya. Berbagai momen dibagikan melalui media sosial dalam bentuk kata-kata, foto, dan video. Perkembangan teknologi yang juga berdampak pada kecanggihan media sosial saat ini yang tidak hanya menjadi media hiburan tapi juga sudah berfungsi ganda menjadi media informasi, media berkreasi, bahkan kini melalui media sosial penggunanya dapat menghasilkan uang.

Selain itu kesadaran bermedia sosial merupakan kondisi di mana generasi muda dapat menggunakan media sosial secara teknis, memahami fitur-fitur yang tersedia di media sosial, mengidentifikasi konten hoaks, menanggapi penyebaran hate speech dengan baik, hingga dapat menciptakan konten kreatif serta menambah relasi dan membuat proyek sosial untuk masyarakat melalui media sosial.

kesadaran bermedia dapat dibangun dari personal lokus, struktur pengetahuan, dan skill. Personal locus merupakan tujuan dan kendali kita akan informasi. Ketika kita menyadari akan informasi yang kita butuhkan, maka kesadaran kita akan menuntun untuk melakukan proses pemilihan informasi secara lebih cepat, pun sebaliknya. Struktur pengetahuan merupakan seperangkat informasi yang terorganisasi dalam pikiran kita. Kita membutuhkan struktur informasi yang kuat akan efek media, isi media, industri media, dunia nyata, dan diri kita sendiri. Skill adalah alat yang kita gunakan untuk menumbuhkan dan meningkatkan kesadaran bermedia yang dimiliki.

\section{Pelaksanaan Kegiatan Pengabdian}

Angkatan Muda Gereja Protestan Maluku Ranting Militia Christy merupakan sebuah organisasi kepemudaan gereja yang berada dalam naungan Gereja Protestan Maluku. Berlokasi di kelurahan Batu Gajah Kelurahan Urimesing Kota Ambon, dengan komposisi kepengurusan yang dipimpin oleh sdri. Nesya Judith Papilaya selaku Ketua dan sdr. Simon Timisela selaku Sekertaris. AM GPM Ranting Solagratia memiliki jumlah anggota aktif sebanyak 15 orang dan jumlah keseluruhan anggota 25 orang.

Kegiatan pengabdian kepada masyarakat yang dilakukan pada Angkatan Muda (AM) Gereja Protestan Maluku Ranting Militia Christy Batu Gajah Ambon, dilaksanakan atas undangan dari pengurus AM GPM Ranting Militia Christy. Setelah melakukan koordinasi antara pengurus AM GPM Ranting Militia Christy, kemudian dilakukan identifikasi permasalahan yang sering dihadapi oleh para kader AM GPM Ranting Militia Christy.

Setelah melakukan identifikasi awal berdasarkan data yang diperoleh dari koordinasi bersama pengurus AM GPM Ranting Militia Christy, maka direncanakan kegiatan pengabdian masyarakat pada tanggal 06 Maret 2021. Setelah dilakukan kegiatan peningkatan kesadaran hukum dan etika memakai media social melalui penyuluhan yang diberikan kepada seluruh kader Angkatan Muda GPM Ranting Militia Christy, ditemukan bahwa generasi muda yang kerap menggunakan Internet untuk mencari beragam informasi dapat menyalagukan informasi tersebut. oleh karena itu adanya perhatian khusus dalam meningkatkan kesadaran dari generasi muda gereja baik dalam menggunakan bahasa yang bijak di media sosial maupun menghindari dampak negatif dari penggunaan media sosial yang dapat merugikan orang lain. 


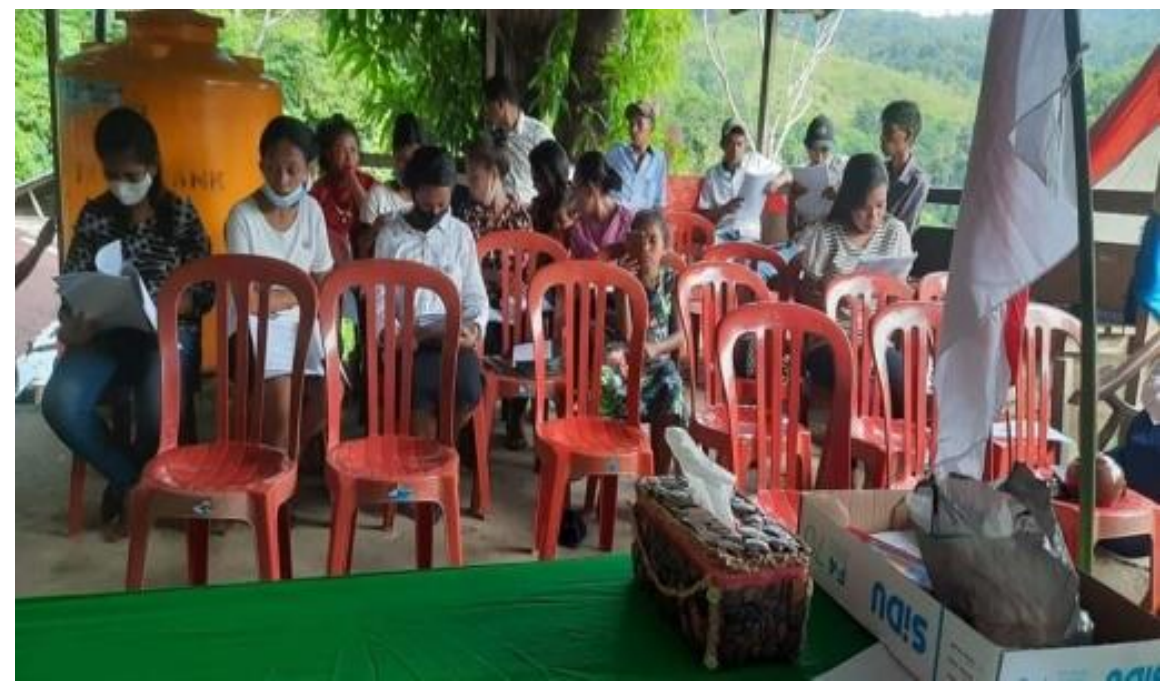

Gambar 1: Kegiatan Penyuluhan Kesadaran Hukum dan Etika Memakai Media social Di AM GPM Ranting Militia Christy

\section{SIMPULAN}

Kegiatan Pengabdian Masyarakat yang diselenggarakan oleh Pengurus Angkatan Muda GPM Ranting Militia Christy bersama dosen pidana Fakultas Hukum Universitas Pattimura bagi kaderkadernya bertujuan agar generasi muda gereja memiliki etika dan kesadaran hukum yang baik dalam bermedia sosial khususnya media sosial baik di Facebook, WhatsApp maupun Instagram. Disamping itu sebagai generasi muda gereja yang baik dan taat hukum dapat menggunakan dan memanfaatkan informasi yang diterimanya dengan baik, selalu waspada dan bertanggung jawab terhadap kebenaran informasi, serta tidak menyebarkan berita hoax, melakukan croscek terlebih dahulu apabila menerima berita, menggunakan etika dalam menulis sesuatu di media sosial tanpa merugikan orang lain. Berita atau tulisan yang disebarkan tidak mengandung hal-hal yang negatif yang merugikan orang lain.

\section{SARAN}

Kesadaran bermedia sosial oleh generasi mudan gereja perlu ditingkatkan melalui pengadaan kegiatan pengabdian masyarakat ataupun penyuluhan terutama dalam mengidentifikasi penyebaran hoaks dan hate speech sehingga dapat menggunakan media sosial dengan bijak.

\section{UCAPAN TERIMA KASIH}

Pada kesempatan ini, kami ingin menyampaikan terima kasih kepada Dekan Fakultas Hukum Universitas Pattimura yang telah mengijinkan kami untuk berbagi ilmu dengan rekan-rekan dari Angkatan Muda GPM Ranting Militia Christy Batu Gajah. Selain itu, kami juga ingin menyampaikan terima kasih kepada para Pengurus Angkatan Muda Gereja Protestan Maluku Ranting Militia Christy Batu Gajah, karena telah mengundang kami untuk berbagi pengetahuan hukum dengan rekan-rekan AM GPM Ranting Militia Christy.

\section{DAFTAR PUSTAKA}

Budi Suhariyanto, (2014). Tindak Pidana Teknologi Informasi (Cybercrime): Urgensi Pengaturan dan Celah Hukumnya, Ed. Ketiga, Jakarta: Raja Grafindo Persada

Burhan Bungin,(2003). Pornomedia: Konstruksi Sosial Telematika dan Perayaan Seks di Media Massa, Jakarta: Prenada Media

Esmi Warassih, (2005), Pranata Hukum Sebuah Telaah Sosiologis, Semarang: PT Suryandaru Utama. Maskun, (2014). Kejahatan Siber: Cyber Crime Suatu Pengantar, Ed. Kedua, Jakarta: Kencana Prenada Media Group

Moh Labib\&Abdul Wahid, (2010). Kejahatan Mayantara (Cyber Crime), Ed. Kedua, Bandung: Refika Aditama

Soerjono Soekanto, (1982), Kesadaran Hukum dan Kepatuhan Hukum, Jakarta: CV Rajawali.

Setyaningsih, R. (2014). Bahaya Berkomunikasi di media sosial. Jurnal Psikologi Proyeksi, Vol. 9 (2), 91-103. 